\section{Floral Crop Production in High Tunnels}

\author{
H. Chris Wien ${ }^{1}$
}

ADDITIONAL INDEX wORDs. floriculture, cut flowers, specialty cut flowers, Association of Specialty Cut Flower Growers

SUMMARY. High tunnels are well suited for use in the production of floral crops, especially cut flowers. Through the increases in temperature afforded at both ends of the growing season, high tunnels allow earlier and later harvests than are possible in the field. During summer, rain protection and a relatively calm environment provides an ideal growing environment to cut flower crops. In U.S. Department of Agriculture (USDA) Hardiness Zones 3 through 5, the higher temperatures of a high tunnel permit culture of warm-season crops like celosia (Celosia argentea) during summer. Cut flower production allows intensive production on a small land area and provides a high level of income. For these reasons, high tunnels have become a standard part of cut flower growers' farms. Most commonly, they are single-bay structures with roll-up sides, but use of multi-bay complexes is becoming more popular for larger-scale growers. In USDA Hardiness Zones of 7 and higher, high tunnels are shaded in summer to lower interior temperatures and enhance production of shade-tolerant species. Overall, techniques of moderating temperature extremes with shading and ventilation, or use of low tunnels inside to increase minimum temperatures are important options for cut flower production. In the presentation, comparisons will be made in growth and earliness of production and yield for several cut flower species grown in the field and an adjacent high tunnel.

A $s$ other presentations in this colloquium have shown, the definition of high tunnels is rather broad, but emphasizes inground production of crops in simple frame structures usually covered by a single layer of clear polyethylene. Thus, when considering production of floral crops in high tunnels, the emphasis is on flowering plants grown for cut flowers, rather than other categories of floriculture products such as bedding plants, potted flowering plants, and foliage plants that are normally grown in containers (Table 1). It may be helpful to briefly summarize the worldwide and North American production of cut flowers, for which the use of high tunnels has become important.

The production of cut flower crops worldwide has undergone profound changes in the last 40 years. Whereas the major cut flower crops [rose (Rosa spp.), carnation (Dianthus caryophyllus), chrysanthemum (Dendranthema xgrandiflorum), and alstroemeria (Alstroemeria spp.)] were grown within North America largely for local consumption, they are now almost exclusively imported from South America (Tables 2 and 3) into the United States (Stewart,

Department of Horticulture, Cornell University, 156 Plant Science Hall, Ithaca, NY 14853

${ }^{1}$ Corresponding author. E-mail: hcw2@cornell.edu.
2007). Domestic production used to be concentrated in greenhouses, but energy and labor costs became prohibitive, and the more ideal yeararound production environment and low cost of labor in the countries near the equator made that shift inevitable (Pertwee, 2003).

High tunnels are widely used in these countries to protect the flowers from rain and wind (Stewart, 2007) (Fig. 1). While production statistics are not separately gathered for flowers grown in glass-covered greenhouses or plastic-covered high tunnels, it is estimated that the majority of the 15,000 ha of flowers grown under protected cultivation in China are grown in the ground in high tunnels (Jiang et al., 2004). The cultivation conditions for roses grown as cut flowers worldwide have been most fully described (Pertwee, 2003), and show that protected cultivation is the norm for countries near the equator, where currently the majority of cut-flower roses are grown (Table 4).

\section{High tunnel production of cut flowers in North America}

With the transfer of production of the major cut flower species to the highland tropics, the North American cut flower industry shifted its focus to flowers that are less easily stored and shipped long distances (Armitage and Laushman, 2003). At the same time, glass-covered greenhouses were used increasingly for production of potted flowering plants and bedding plants grown in containers, relegating cut flower production to less expensive structures such as high tunnels and to outdoor fields. Production thus became largely seasonal and has involved a large number of ornamental species.

High tunnels provide a number of advantages for the growing of cut flowers. In the northern parts of the United States and Canada, they provide protection against low temperatures, allowing the crop to be planted as much as a month before the same crop can be grown in the open field (Table 5). In the fall, the plants can be kept growing for several weeks longer, especially if the field is subject to early frosts. The protected and relatively calm environment of the high tunnel allows plants to grow taller than in an exposed field environment (Table 6). Plants in tunnels are not exposed to rain, and thus flower quality is maintained and disfiguring diseases are minimized. In the southern states, the milder winters and higher light levels allow cut flower production over the winter, and species can be grown that would be killed by the cold outdoor conditions.

A large number of cut flower species can be successfully grown in high tunnels. Although the list may not be as long as the 87 species described in the Armitage and

\begin{tabular}{llll}
\hline $\begin{array}{l}\text { Units } \\
\begin{array}{l}\text { To convert U.S. to SI, } \\
\text { multiply by }\end{array}\end{array}$ & U.S. unit & SI unit & $\begin{array}{l}\text { To convert SI to U.S., } \\
\text { multiply by }\end{array}$ \\
\hline 0.4047 & acre $(\mathrm{s})$ & $\mathrm{ha}$ & 2.4711 \\
2.54 & inch $(\mathrm{es})$ & $\mathrm{cm}$ & 0.3937 \\
0.0254 & $\mathrm{mil}$ & $\mathrm{mm}$ & 39.3701 \\
33.9057 & $\mathrm{oz} / \mathrm{yard}^{2}$ & $\mathrm{~g} \cdot \mathrm{m}^{-2}$ & 0.0295 \\
$\left({ }^{\circ} \mathrm{F}-32\right) \div 1.8$ & ${ }^{\circ} \mathrm{F}$ & ${ }^{\circ} \mathrm{C}$ & $\left(1.8 \times{ }^{\circ} \mathrm{C}\right)+32$
\end{tabular}


Table 1. Production of floriculture crops in the United States in 2005 (Jerardo, 2006).

\begin{tabular}{lc}
\hline Category & $\begin{array}{c}\text { United States } \\
\text { value (billion \$) }\end{array}$ \\
\hline $\begin{array}{l}\text { Bedding and garden } \\
\text { plants }\end{array}$ & 2.61 \\
$\begin{array}{l}\text { Potted flowering } \\
\quad \text { plants }\end{array}$ & 0.81 \\
Foliage plants & 0.72 \\
Cut flowers & 0.40 \\
Total & 5.08 \\
\hline
\end{tabular}

Laushman (2003) manual on specialty cut flowers, they range from geophytes to annuals and perennials, along with some woody species (Byczynski 2003, 2005). In northern areas, the first crop such as tulip (Tulipa spp.), ranunculus (Ranunculus asiaticus), and anemone (Anemone coronaria), is often cold hardy and frequently planted in artificial soil in plastic crates (Byczynski, 2005). This crop may then be followed by a transplanted crop of snapdragon (Antirrrbinum majus), stock (Matthiola incana), sunflower (Helianthus annuus), and godetia (Clarkia spp.), before a main season species that grows well in warm conditions is planted. Such species include lisianthus (Eustoma grandiflora), trachelium (Trachelium caeruleum), celosia, and amaranth (Amaranthus spp.). Many other species are also possible, and are chosen based on their temperature preferences and market potential. The choice of species to be included for marketing in the fall needs to include a consideration of color preferences for fall flowers, emphasizing the deeper orange and red shades. Specific varieties of sunflower, small-fruited varieties of

Table 2. Cut flower sales in the United States, and the proportion produced in the country (Stewart, 2007).

\begin{tabular}{llcc}
\hline Crop & \multicolumn{1}{c}{ Latin name } & $\begin{array}{c}\text { Cut flower sales } \\
\text { (billion stems) }\end{array}$ & $\begin{array}{c}\text { Domestically } \\
\text { produced (\%) }\end{array}$ \\
\hline Rose & Rosa spp. & 1.45 & 0.01 \\
Carnation & Dianthus caryophyllus & 0.61 & 1.5 \\
Chrysanthemum & Dendranthema $\times$ grandiflorum & 0.51 & 2.4 \\
Alstroemeria & Alstroemeria spp. & 0.27 & 2.7 \\
Tulip & Tulipa spp. & 0.22 & 54.1 \\
Gerbera & Gerbera jamesonii & 0.21 & 50.6 \\
Lily & Lilium spp. & 0.16 & 71.8 \\
Gladiolus & Gladiolus spp. & 0.12 & 87.0 \\
Iris & Iris spp. & 0.10 & 87.0 \\
\hline
\end{tabular}

Table 3. United States cut flower imports by country of origin (Stewart, 2007).

\begin{tabular}{lcc}
\hline Country & $\begin{array}{c}\text { Import } \\
\text { quantity } \\
\text { (million } \\
\text { stems) }\end{array}$ & $\begin{array}{c}\text { Import } \\
\text { value } \\
\text { (million \$) }\end{array}$ \\
\hline Colombia & 2254 & 418 \\
Ecuador & 468 & 129 \\
Costa Rica & 57 & 23 \\
Thailand & 49 & 5 \\
Mexico & 22 & 20 \\
Guatemala & 15 & 4 \\
The & & \\
$\quad$ Netherlands & 8 & 65 \\
Kenya & 8 & 1 \\
\hline
\end{tabular}

pepper (Capsicum annumm) that bear fruit above the canopy, and grass species that have ornamental seed heads would fit into this category.

One dominant feature of hightunnel cut flower production is the desire to keep this relatively expensive growing area filled with growing crops for as much of the season as possible. A particular crop may therefore not be as high yielding in the tunnel as outside, when an individual crop such as snapdragon is considered (Table 6). The grower often pulls plants out of the tunnel even before all the stems have been harvested to make room for a more valuable crop that will fill out the rest of the growing season. In the field, where weather conditions may only allow one crop per season, time pressure is less, and all the marketable stems on that crop can be harvested over a longer season. When productivity is compared on a per unit time basis, the high-tunnel plants produce more stems per week than those grown outside in almost every case (Table 6).

Hartecthology · January-March 2009 19(1)
The large number of species that are grown as cut flowers provide one important advantage in the area of pest and disease management: a wide choice of genera among which to rotate to avoid insect and pathogen buildup. As with the reports of disease problems with other types of crops, powdery mildew (Erisyphe, Oidium, and other genera) has been an important disease among susceptible flower species in high tunnels (Byczynski, 2003). The most persistent insect pest in our trials has been the aphid (Myzus persicae, Aphis gossypii, and other species), especially late in the season. Others have also seen more pressure from thrips (Frankliniella spp.) inside high tunnels than on the same crop outside, presumably because the higher temperature and protection from rainfall keep the insects from being washed off.

\section{Special challenges for high tunnel cut flower production}

Extending the season with a high tunnel may expose plants to environmental conditions they would not ordinarily face in a summer growing season. With some species, the daylength early in the season may be short enough to trigger flowering much earlier than in a normal season. For instance, many sunflower varieties are short-day plants and are sensitive to the daylength during the first 3 weeks after emergence (Blacquiere et al., 2002) (Fig. 2). If these sensitive varieties are transplanted into a tunnel in mid-April from a greenhouse without artificial light, the plants will flower 3 weeks earlier than normal, and with much smaller flowers (Wien, 2007).

A related problem may occur at the end of the season with flower species that require long days for flowering. Rudbeckia (Rudbeckia birta) is such a species that, if planted in midsummer in a high tunnel anticipating a fall flower production season, will disappoint by producing a few sessile flowers or none, rather than the showy blooms when planted in spring (Kochanov and Chailakhyan, 1986) (Fig. 3). For production of long flower stems in this species, artificial light to extend the day or interrupt the night would need to be supplied during the fall production season in the tunnel (Wien, 2006a). 


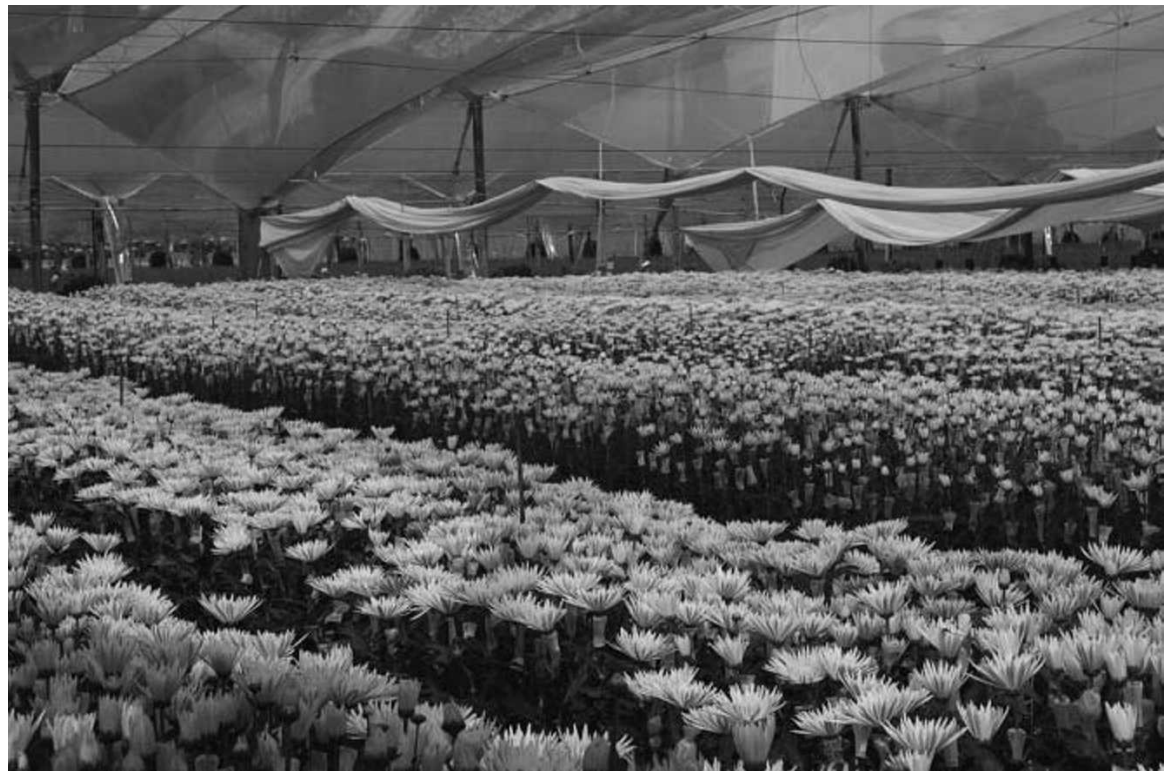

Fig. 1. Chrysanthemum production in high tunnels in Colombia (photo courtesy of J. Dole).

Table 4. Worldwide rose production areas (Pertwee, 2003).

\begin{tabular}{lcc}
\hline Country & Year & $\begin{array}{c}\text { Rose } \\
\text { production } \\
(\mathbf{h a})^{\mathbf{z}}\end{array}$ \\
\hline Ecuador & 2003 & 2012 \\
Colombia & 2003 & 1600 \\
Kenya & 2002 & 1380 \\
The Netherlands & 2002 & 880 \\
Zimbabwe & 2002 & 600 \\
France & 2000 & 440 \\
United States & 2002 & 229 \\
\hline
\end{tabular}

Temperature management of high tunnels in which ventilation is manually operated is a major deterrent to tunnel adoption. Tunnels experience temperatures at both extremes. In northern locations, temperatures below freezing early and late in the season can damage crops in a high tunnel. The transparency of polyethylene to infrared radiation allows the heat that builds up inside during the day to dissipate quickly at night. If tunnel vents are closed, the tunnel may "supercool," with temperatures inside falling below those immediately outside (Albright et al., 1985). The warmer air outside is prevented from warming up the atmosphere in the tunnel. Fortunately, polyethylene manufacturers can decrease the transparency of the film to infrared radiation (termed "infrared-blocking"), and thereby reduce the heat loss (Montero, 1985).

Another method of reducing heat loss from high tunnels is placing low tunnel covers of various materials over the plants. As shown in Fig. 4, the type of material used can allow for as much as $10^{\circ} \mathrm{F}$ higher temperatures under the low tunnel inside a high tunnel compared with the outside air.

On sunny days, temperatures can build up to dangerously high levels in high tunnels unless prompt and effective ventilation is practiced. Roll-up sides, large end doors, and gable vents are common features in high tunnels that can at least keep maximum temperatures close to those outside the tunnel (Fig. 5 ). To moderate temperatures, it may be possible to install shade screens, especially because reduced irradiance would stimulate stem extension. The trade-off between improved growth temperature and reduced productivity due to lower photosynthesis rates needs to be explored for specific cut flower species to determine what screen

Table 5. Transplant dates, first harvest dates, and yield per plant for six cut flower species grown in a high tunnel and outdoors at Ithaca, NY, in 2004.

\begin{tabular}{|c|c|c|c|c|c|c|}
\hline \multirow[b]{2}{*}{ Species } & \multicolumn{2}{|c|}{ Transplant dates } & \multicolumn{2}{|c|}{ First harvest dates } & \multicolumn{2}{|c|}{ Yield (stems/plant) } \\
\hline & Tunnel & $\overline{\text { Outside }}$ & Tunnel & Outside & Tunnel & Outside \\
\hline Lisianthus (Eustoma grandiflora) & 17 May & 17 May & 16 June & 25 July & 4.6 & 3.5 \\
\hline Zinnia (Zinnia elegans) & 30 Apr. & 25 May & 23 June & 23 July & 8.2 & 13.6 \\
\hline Dianthus (Dianthus spp.) & 30 Apr. & 15 May & 18 June & 1 July & 6.8 & 8.3 \\
\hline Foxglove (Digitalis purpurea) & 15 Apr. & 15 May & 7 July & 20 July & 16.0 & 19.6 \\
\hline
\end{tabular}

Table 6. Stem length, yield, time period from first to last harvest, and productivity of lisianthus and snapdragon grown in a high tunnel and outside at Ithaca, NY, in 2004 and 2005.

\begin{tabular}{|c|c|c|c|c|c|c|c|c|}
\hline \multirow[b]{2}{*}{ Species } & \multicolumn{2}{|c|}{$\begin{array}{c}\text { Stem length } \\
(\mathrm{cm})^{\mathrm{z}}\end{array}$} & \multicolumn{2}{|c|}{$\begin{array}{c}\text { Yield } \\
\text { (stems/plant) }\end{array}$} & \multicolumn{2}{|c|}{$\begin{array}{c}\text { Harvest duration } \\
\text { (d) }\end{array}$} & \multicolumn{2}{|c|}{$\begin{array}{c}\text { Productivity } \\
\text { (stems/plant per week) }\end{array}$} \\
\hline & Tunnel & Outside & Tunnel & Outside & Tunnel & Outside & Tunnel & Outside \\
\hline Lisianthus 2004 & 50 & 46 & 4.6 & 3.5 & 69 & 79 & 0.47 & 0.31 \\
\hline Lisianthus 2005 & 47 & 44 & 8.1 & 5.9 & 113 & 95 & 0.50 & 0.43 \\
\hline Snapdragon 2004 & 57 & 60 & 5.0 & 7.1 & 61 & 86 & 0.57 & 0.58 \\
\hline Snapdragon 2005 & 65 & 54 & 6.5 & 7.5 & 77 & 117 & 0.59 & 0.45 \\
\hline
\end{tabular}

${ }^{2} 1 \mathrm{~cm}=0.3937$ inch. 


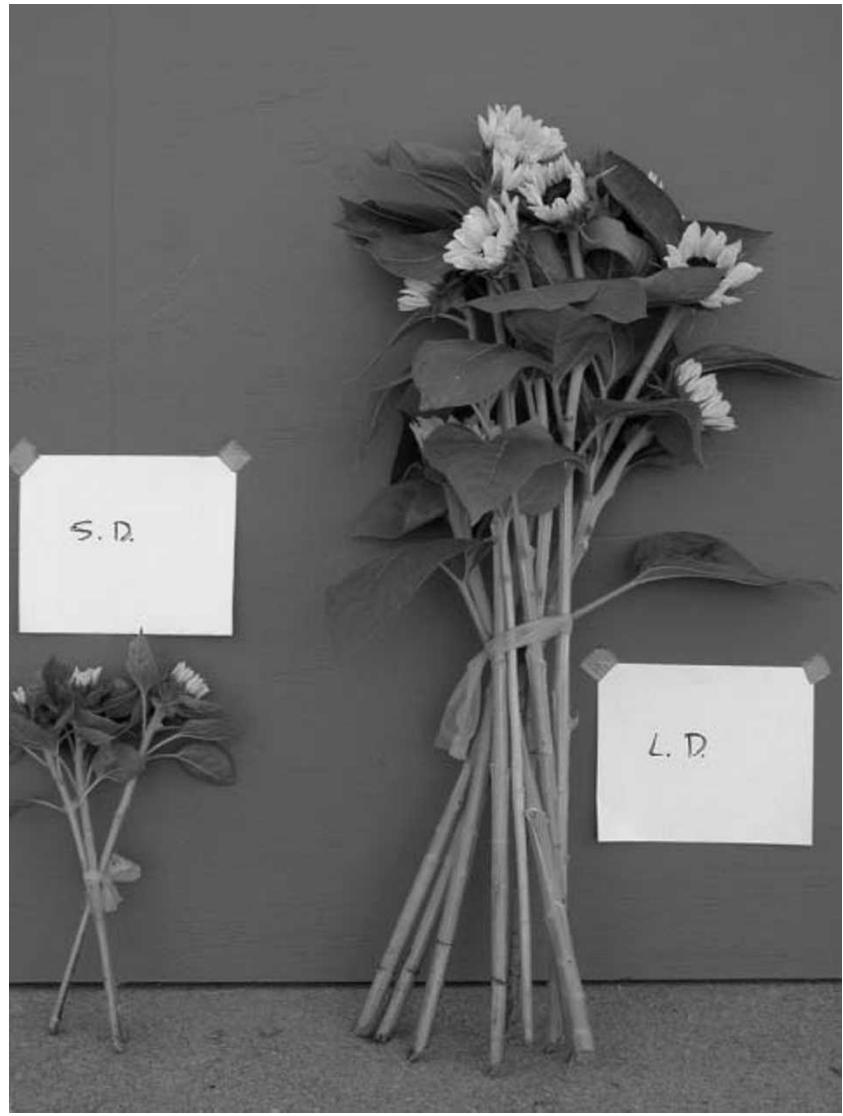

Fig. 2. 'Premier Light Yellow' sunflower exposed to 3 weeks of 12-h (left) or 16-h (right) photoperiod in a greenhouse before transplanting to the field in Ithaca, NY. Plants on left were sown 3 weeks before those on the right.

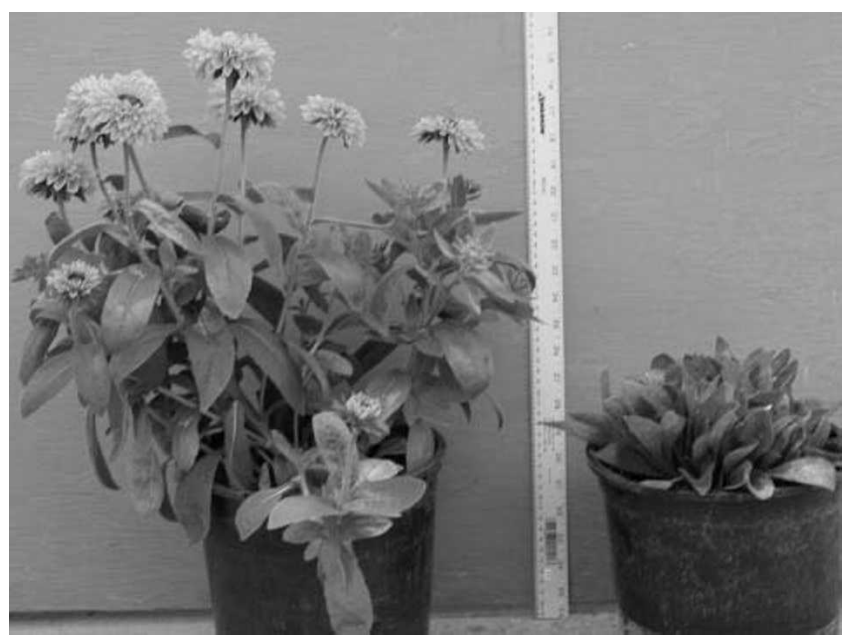

Fig. 3. 'Goldilocks' rudbeckia grown in 16-h (left) or 12-h daylength (right) for the entire growth period, in a greenhouse in Ithaca, NY.

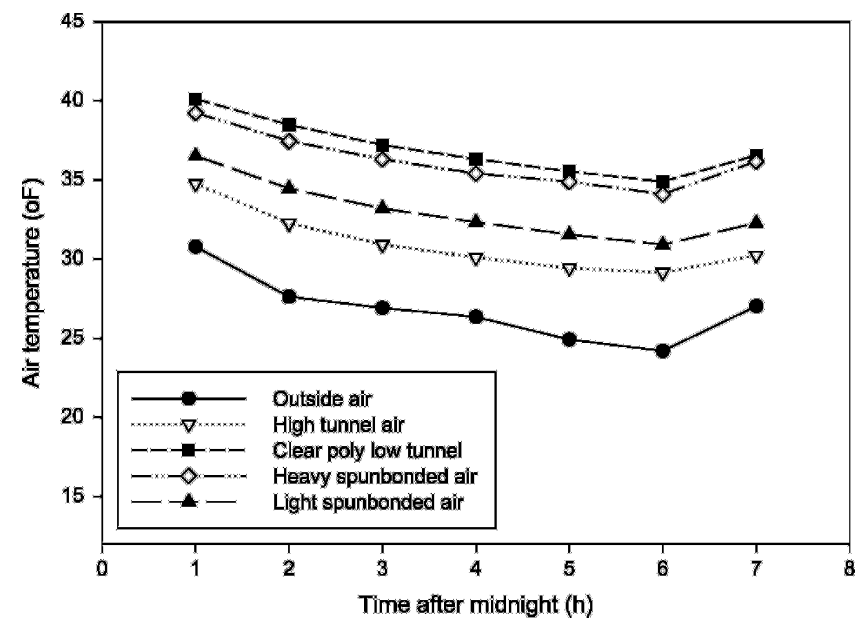

Fig. 4. Effect of various low tunnel cover materials on air temperatures in low tunnels inside a high tunnel and outside. Materials compared include clear polyethylene (poly) [6 mils $(0.15 \mathrm{~mm})$ thick], heavy spunbonded fabric $\left[2.0 \mathrm{oz} / \mathrm{yd}^{2}\left(67.81 \mathrm{~g} \cdot \mathrm{m}^{-2}\right)\right]$, and light spunbonded fabric $\left[0.6 \mathrm{oz} / \mathrm{yd}^{2}\left(20.34 \mathrm{~g} \cdot \mathrm{m}^{-2}\right)\right]$. Temperatures were taken 26 Apr. 2006. $\left[\left({ }^{\circ} \mathrm{F}-32\right) \div 1.8={ }^{\circ} \mathrm{C}\right]$.

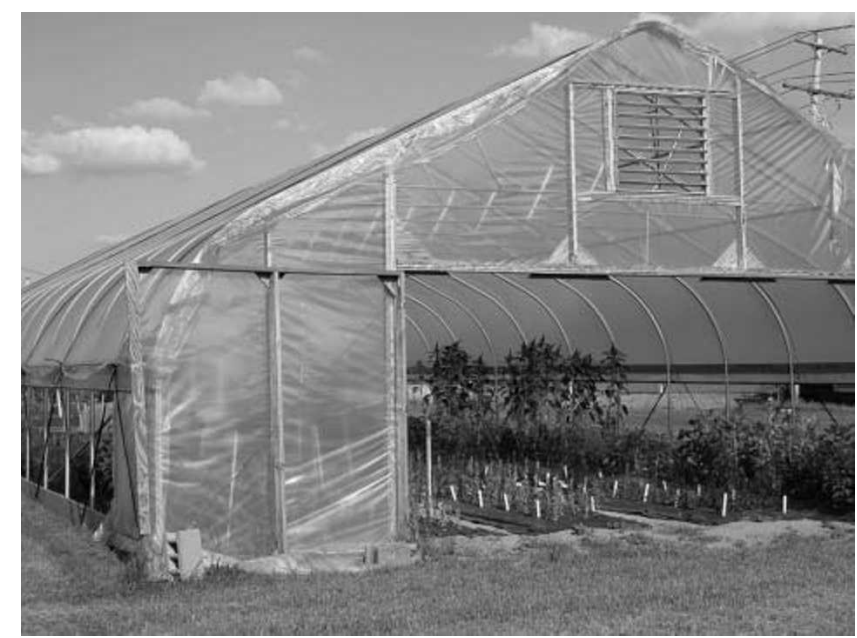

Fig. 5. High tunnel at Ithaca, NY, showing roll-up sides, large end doors, and gable-end vents to maximize air exchange and reduce temperature buildup in summer. material and what level of shade would be optimum.

An additional challenge, related to moderating high temperature in the tunnel is the air movement through the structure. Although air movement is necessary to prevent temperature buildup, encouraging wind that causes excessive plant movement will lead to shorter-stemmed flowers that have low value as cut flowers. In exposed sites, it may be necessary to install windbreaks that allow efficient air exchange without leading to plant stunting (Wien, 2006b).

In summary, high tunnels provide an environment in which cut flowers that are not easily stored 
and shipped can be produced. The protection afforded from wind and rain, and extension of the growing season outweigh the disadvantages of the higher labor requirement than production outside. A wide range of flower species can be grown in high tunnels, and choice of crop will depend on the time of year and market demands. Extending the season by planting earlier or later than normal using high tunnels exposes plants to unusual daylengths and temperatures. Investigating the effect of those conditions on plant performance may become necessary to optimize production.

\section{Literature cited}

Albright, L.D., I. Seginer, L.S. Marsh, and A. Oko. 1985. In-situ thermal calibration of unventilated greenhouses. J. Agr. Eng. Res. 31:265-281.
Armitage, A.M. and J.M. Laushman 2003. Specialty cut flowers. 2nd ed. Timber Press, Portland, OR.

Blacquiere, T., N. Straver, and D. van den Berg. 2002. Possibilities for using photoperiodism to program flowering of sunflowers (Helianthus annuus) in the greenhouse and in the open. Acta Hort. 580:101-109.

Byczynski, L. (ed.). 2003. The hoophouse handbook. Fairplain Publ., Lawrence. KS.

Byczynski, L. (ed.). 2005. Extending the season. Fairplain Publ., Lawrence, KS.

Jerardo, A. 2006. Floriculture and nursery crops yearbook. 5 Mar. 2008. <http:// usda.mannlib.cornell.edu/MannUsda/ viewDocumentInfo.do?documentID= $1448>$.

Jiang, W., D. Qu, D. Mu, and L. Wang. 2004. Protected cultivation of horticultural crops in China. Hort. Rev. (Amer. Soc. Hort. Sci.) 30:115-162.
Kochanov, V.G. and M.K. Chailakhyan. 1986. Rudbeckia, p. 295-320. In: A.H. Halevy (ed.). CRC handbook of flowering, Vol. 5. CRC Press, Boca Raton, FL.

Montero, A.A. 1985. Climate under plastic in the Almeria area. Acta Hort. 170:227-234.

Pertwee, J. 2003. Production and marketing of roses, II. Reed Business Information, Doetinchem, The Netherlands.

Stewart, A. 2007. Flower confidential. Algonquin Books, Chapel Hill, NC.

Wien, H.C. 2006a. Growing black-eyed susan and sunflower out of season. Growing Market 15(6):17-18.

Wien, H.C. 2006b. Can we grow cut flowers with longer stems? Cut Flower Qrtly. 18(3):32-33.

Wien, H.C. 2007. Day-neutral sunflowers: Do they exist, and what difference does it make? Cut Flower Qrtly. 19(1):48-49. 